J. Pijar MIPA, Vol. VI No.2, September : 50 - 54

ISSN 1907-1744

\title{
EFEKTIVITAS METODE PEMBELAJARAN PEMECAHAN MASALAH (Problem Solving) DALAM MENINGKATKAN HASIL BELAJAR BIOLOGI SISWA KELAS X SMA NEGERI 3 MATARAM TAHUN PEMBELAJARAN 2010/2011
}

\author{
Khairun Nisa ${ }^{1}$, Dwi Soelistya Dyah Jekti², Dewa Ayu Citra Rasmi \\ ${ }^{1}$ Alumnus Program Studi S1 Pendidikan Biologi FKIP Unram, Mataram \\ ${ }^{2}$ Program Studi Pendidikan Biologi FKIP Unram, Mataram \\ Email: dewaayucitrarasmi@yahoo.com
}

\begin{abstract}
Abstrak : Penelitian dilakukan untuk menganalisis apakah metode pembelajaran pemecahan masalah (Problem Solving) efektif dalam meningkatkan hasil belajar biologi siswa kelas X SMA Negeri 3 Mataram tahun pembelajaran 2010/2011. Jenis penelitian eksperimen semu. Populasi penelitian adalah semua kelas X SMA Negeri 3 Mataram tahun pembelajaran 2010/2011. Sampel penelitian ini adalah kelas $\mathrm{X}^{10}$ sebagai kelas kontrol dan kelas $\mathrm{X}^{12}$ sebagai kelas eksperimen dengan jumlah siswa masingmasing 31 orang. Pengambilan sampel dengan teknik Simple Random Sampling. Instrumen penelitian berupa tes hasil belajar, lembar observasi aktivitas guru dan siswa. Pre-tes dilakukan untuk mengetahui kemampuan awal dan Post-test untuk mengetahui hasil belajar siswa setelah diberikan perlakuan yang berbeda. Data hasil belajar kognitif dianalisis dengan menggunakan uji-t polled varians terhadap selisih nilai pre-test dan pos-test. Hasil penelitian diperoleh rata-rata kelas eksperimen lebih tinggi dari kelas kontrol, baik pada pre-test maupun post-test. Hasil uji hipotesis menunjukkan nilai $\mathrm{t}_{\text {hitung }}>\mathrm{t}_{\text {tabel }}$, yakni 2,987>1,671 pada taraf kesalahan 5\%, yang menunjukkan peningkatan hasil belajar yang signifikan. Data hasil belajar untuk aspek afektif dianalisis menggunakan skala penilaian dan aspek psikomotor menggunakan skala likert. Hasil penilaian menunjukkan peningkatan hasil belajar dengan rata-rata sangat baik pada kelas eksperimen, dan beberapa kategori baik dan kurang baik pada kelas kontrol. Hal tersebut menunjukkan bahwa penerapan metode Problem Solving efektif dalam meningkatkan hasil belajar biologi siswa kelas $\mathrm{X}$ SMA Negeri 3 Mataram tahun pembelajaran 2010/2011.
\end{abstract}

Kata kunci: metode Problem Solving, hasil belajar biologi

\begin{abstract}
This research is aimed to analyze the effectiveness of problem solving methods to increase biological learning attainment of grade X student of Mataram High School in The Academic Year 2010/2011. This research used quasi experiment design. The population of the research was grade X students of Mataram Senior High School 3 in The Year 2010/2011. The samples of the research were 2 classes of 12 classes of grade $X$ students. Student of the $\mathrm{X}^{10}$ was treated as experimental class and student of the $\mathrm{X}^{12}$ were untreated as control class. Simple random sampling was used to determined the sample, and observation sheet both of teacher and students were used as instrument in this research. Pretest was held to get information about students background knowledge of both classes and post test was held to know student achievement after given the treatment. The data of cognitive assessment was analysed using t- test polled variance according to difference between pretest and post test score. The result showed that everage score in experiment class was higher than the control class for both pretest or post test score. However, the t-test analyze suggest that the achievement of cognitive score was significantly in experimental class than the control class. The student assessment data of affective aspect was analyzed using score scale while psychomotoric aspect was analyzed using likert scale. The result shows that the experimental class achieved higher scale of category then the control class as this class achieved only medium and low category scale. This suggest that the application of problem solving learning methods was effective for increasing biological learning attainment of grade X student of Mataram Senior High School 3 in The Year of 2010/2011.
\end{abstract}

Keywords : Problem Solving Methods, students learning attainment

\section{PENDAHULUAN}

Belajar sebagai aktivitas mental/psikis yang berlangsung dalam interaksi aktif dengan lingkungan, yang menghasilkan perubahan dalam pemahaman, keterampilan dan sikap. Belajar dapat membawa perubahan dalam diri seseorang dan dari perubahan akan diperoleh kecakapan baru melalui suatu usaha [1]. Oleh karena itu, dalam proses pembelajaran perlu adanya suasana yang terbuka, akrab dan saling menghargai. Kurikulum 2006 yang diterapkan saat ini pada pendidikan Ilmu Pengetahuan 
Alam (IPA) diharapkan dapat menjadi wahana bagi peserta didik untuk mempelajari diri sendiri dan alam sekitar, serta proses pengembangan lebih lanjut dalam penerapannya di dalam kehidupan sehari-hari. Proses pembelajarannya menekankan pada pemberian pengalaman langsung untuk mengembangkan kompetensi agar menjelajahi dan memahami alam sekitar secara ilmiah.

Metode pembelajaran pemecahan masalah (Problem solving) merupakan salah satu metode pembelajaran yang dapat digunakan untuk memperbaiki sistem pembelajaran. Selama ini kemampuan siswa untuk dapat menyelesaikan masalah kurang diperhatikan oleh guru [2]. Akibatnya ketika siswa menghadapi permasalahan tidak bisa menyelesaikan yang dapat berdampak pada menurunnya motivasi belajar siswa di sekolah maupun di rumah.

Berdasarkan hasil observasi dan wawancara dengan guru dan siswa kelas X SMA Negeri 3 Mataram, diketahui bahwa materi ekosistem adalah salah satu materi pelajaran yang dianggap sulit, karena sering membutuhkan analisis dalam menjawab soalsoal evaluasinya. Dari alasan di atas, maka perlu diberikan suatu metode pembelajaran alternatif untuk mengatasi kesulitan tersebut, salah satunya adalah metode pembelajaran pemecahan masalah (problem solving). Metode pembelajaran pemecahan masalah (problem solving) adalah suatu penyajian materi pelajaran dengan menghadapkan siswa kepada permasalahan yang harus dipecahkan atau diselesaikan untuk mencapai tujuan pembelajaran [3]. Kegiatan pembelajaran untuk menyelesaikan permasalahan dapat dilakukan secara berkelompok.Karena penerapan model pembelajaran kelompok dengan bimbingan guru yang intensif dapat memberikan pengaruh yang positif terhadap pembelajaran. Tujuan yang ingin dicapai dalam penelitian ini adalah menganalisis apakah metode pembelajaran pemecahan masalah (problem solving) efektif dalam meningkatkan hasil belajar biologi siswa kelas X SMA Negeri 3 Mataram tahun pembelajaran 2010/2011.

\section{METODE PENELITIAN}

Penelitian ini bersifat quasi experiment (eksperimen semu).Variabel bebas dalam penelitian ini adalah pembelajaran dengan metode pembelajaran pemecahan masalah (problem solving) sedang variabel terikatnya adalah hasil belajar siswa dengan pokok bahasan ekosistem. Rancangan penelitian yang digunakan adalah desain pre-experimental jenis Pre-test and Post-test Group Design [4]. Kelompok eksperimen diberi perlakuan dengan penerapan metode pembelajaran pemecahan masalah (Problem solving) pokok bahasan ekosistem dan kelompok kontrol diberikan perlakuan secara konvensional. Pretes dan post-tes dengan bentuk pilihan ganda dan jumlah yang sama diberikan pada kelompok perlakuan maupun kelompok kontrol.

Uji hipotesis digunakan rumus ttes polled varians dan ditekankan pada aspek kognitif [5]. Kemampuan afektif dan psikomotor siswa dianalisis dengan mencari mean ideal dan standar deviasi ideal dengan menggunakan katagori sangat aktif, aktif,cukup aktif, kurang aktif, sangat kurang aktif. Sedangkan penilaian untuk lembar observasi kegiatan guru dianalisis dengan cara mengakumulasikan skor yang diperoleh dari IPKG [6] yang telah ditetapkan dengan skala penilaian, dengan kategori penilaian baik sekali, baik,cukup, dan kurang. Selanjutnya dilakukan penghitungan dengan prosentase untuk tiap kategori penilaian.

\section{HASIL DAN PEMBAHASAN}

Hasil belajar siswa kelas kontrol dan kelas eksperimen pada pokok bahasan "Ekosistem" dapat dilihat pada tabel 1.

Tabel 1. Hasil Belajar Siswa Pokok Bahasan "Ekosistem"

\begin{tabular}{|c|c|c|c|c|c|c|c|c|c|}
\hline \multirow{3}{*}{ Kelompok } & \multicolumn{2}{|c|}{ Nilai Rata-rata } & \multicolumn{2}{|c|}{ Nilai Tertinggi } & \multicolumn{2}{|c|}{ Nilai Terendah } & \multirow{3}{*}{ Beda } & \multirow{2}{*}{\multicolumn{2}{|c|}{ t-test }} \\
\hline & \multirow{2}{*}{ Pretes } & \multirow{2}{*}{ Postes } & \multirow{2}{*}{ Pretes } & \multirow{2}{*}{ Postes } & \multirow{2}{*}{ Pretes } & \multirow{2}{*}{ Postes } & & & \\
\hline & & & & & & & & t-tabel & t-hitung \\
\hline Eksperimen & 46,10 & 80,61 & 60 & 92 & 30 & 60 & 34,51 & & \\
\hline Kontrol & 44,13 & 71 & 61 & 85 & 25 & 55 & 26,87 & 1,671 & 2,987 \\
\hline Beda & 1,97 & 9,61 & 1 & 7 & 5 & 5 & 7,67 & & \\
\hline
\end{tabular}


Hasil post-test (tabel 1) menunjukkan terjadi peningkatan yang lebih tinggi pada nilai rata-rata kelas eksperimen. Pernyataan ini dibuktikan dari hasil analisis data untuk nilai rata-rata post-test kelas eksperimen $(80,61)$ lebih tinggi daripada kelas kontrol (71) dengan perbedaan diantara kedua kelas sebesar 9,61. Berdasarkan analisis uji-t diperoleh harga $t_{\text {hitung }}$ sebesar 2,987dan harga $t_{\text {tabel }}$ pada taraf kesalahan $5 \%$ dan db 60 yaitu sebesar 1,671. Karena $t_{\text {hitung }}>t_{\text {tabel }}$, maka hipotesis diterima.Dengan demikian, dapat disimpulkan bahwa penerapan metode pembelajaran problem solving efektif dalam meningkatkan hasil belajar (kognitif) biologi siswa kelas X SMA Negeri 3 Mataram tahun pembelajaran 2010/2011. Sehingga, pembelajaran dengan metode pemecahan masalah (problem solving) dapat menjadi salah satu pembelajaran alternatif yang dapat diterapkan untuk meningkatkan hasil belajar siswa pada mata pelajaran IPA khususnya Biologi.

Peningkatan hasil belajar tersebut diantaranya disebabkan karena metode pembelajaran pemecahan masalah (problem solving) dapat merangsang rasa ingin tahu siswa terhadap beberapa permasalahan yang terkait dengan materi ekosistem yang mampu meningkatkan semangat siswa untuk belajar. Sehingga metode pembelajaran problem solving memberikan pengaruh nyata terhadap peningkatan hasil belajar siswa.Peningkatan hasil belajar dengan penerapan metode problem solving disebabkan oleh beberapa faktor diantaranya, siswa dapat bekerja sama dengan siswa lain dan dapat berkreasi untuk menganalisis serta mengambil keputusan dalam memecahkan permasalahan yang diberikan [5]. Selain itu, karena metode ini menerapkan bimbingan guru dan antar teman dalam kelompok yang dapat membantu siswa untuk lebih menguasai materi, sehingga siswa tidak mudah lupa dengan materi yang dipelajari, dengan demikian sangat mendukung terselenggaranya pembelajaran yang lebih baik dan tujuan pembelajaran dapat tercapai. Selain itu pada proses pembelajaran ini, guru dan siswa melakukan kegiatan saling mengisi dengan cara bertukar fikiran mengenai isi, proses dan hasil kegiatan pembelajaran sehingga siswa dapat mengembangkan pendapat serta gagasannya secara kreatif [7].

Keterlibatan siswa dalam menemukan pengetahuan sendiri memberikan sumbangan nyata terhadap kemampuan berpikirnya. Hal tersebut sesuai dengan kelebihan yang dimiliki oleh metode pemecahan masalah yaitu melatih siswa untuk berpikir dan bertindak kreatif, memecahkan masalah yang dihadapi secara realistis, dan merangsang perkembangan kemajuan berpikir siswa untuk menyelesaikan masalah yang dihadapi dengan cepat dan tepat [8]. Sementara pengajaran penyelesaian masalah merupakan tindakan guru dalam mendorong siswa agar menerima tantangan dari pertanyaan yang bersifat menantang, dan mengarahkan siswa agar dapat menyelesaikan pertanyaan tersebut [9].

Selisih nilai pre-test ke post-test yang lebih rendah pada kelas kontrol (tabel 1) diperkirakan karena metode yang diterapkan kurang memicu partisipasi siswa. Metode pembelajaran konvensional pada penerapannya di kelas siswa hanya mendengarkan dan mencatat penjelasan yang diberikan oleh guru sehingga kurang memotivasi siswa pada kegiatan pembelajaran. Pembelajaran dengan metode ceramah, guru sebagai sumber informasi, sedangkan siswa jarang mengajukan pertanyaan yang menggugah semangat belajar dan siswa memandang ilmu sebagai informasi yang dipelajari [10].

Berdasarkan data hasil penilaian afektif siswa pada kelas eksperimen dan kelas kontrol, terdapat 10 indikator yang dinilai dengan penskoran 1-5 dan dikonsultasikan pada skala penilaian untuk menentukan kategori yang diperoleh. Penilaian yang dilakukan di kelas eksperimen pada pertemuan 1 diperoleh hasil untuk kategori sangat baik pencapaiannya sebesar $19,35 \%$, baik $70,97 \%$, kurang baik $9,68 \%$, dan buruk $0 \%$. Sedangkan pada pertemuan ke-2 dan pertemuan ke-3,

Tabel 2 Penilaian Afektif Kelas Eksperimen

\begin{tabular}{|c|l|l|l|l|l|l|l|l|}
\hline \multirow{2}{*}{$\begin{array}{l}\text { Perte } \\
\text { muan } \\
\text { ke }\end{array}$} & \multicolumn{9}{|c|}{ Persentase Minat dan Sikap Siswa } \\
\cline { 2 - 10 } & \multicolumn{2}{|c|}{ Sangat Baik } & \multicolumn{2}{c|}{ Kaik } & \multicolumn{2}{c|}{ Kurang Baik } & \multicolumn{2}{c|}{ Buruk } \\
\hline & $\begin{array}{l}\text { Kelas } \\
\text { Ekspe } \\
\text { rimen }\end{array}$ & $\begin{array}{l}\text { Kelas } \\
\text { kontrol }\end{array}$ & $\begin{array}{l}\text { Kelas } \\
\text { Ekspe } \\
\text { rimen }\end{array}$ & $\begin{array}{l}\text { Kelas } \\
\text { Kontrol }\end{array}$ & $\begin{array}{l}\text { Kelas } \\
\text { Ekspe } \\
\text { Rimen }\end{array}$ & $\begin{array}{l}\text { Kelas } \\
\text { Kontrol }\end{array}$ & $\begin{array}{l}\text { Kelas } \\
\text { Ekspe } \\
\text { rimen }\end{array}$ & $\begin{array}{l}\text { Kelas } \\
\text { Kontrol }\end{array}$ \\
\hline 1. & $19,35 \%$ & $6,40 \%$ & $70,97 \%$ & $77,70 \%$ & $9,68 \%$ & $15,90 \%$ & $0 \%$ & $0 \%$ \\
\hline 2. & $32,26 \%$ & $0 \%$ & $67,74 \%$ & $64,52 \%$ & $0 \%$ & $35,48 \%$ & $0 \%$ & $0 \%$ \\
\hline 3. & $48,39 \%$ & $13,23 \%$ & $51,61 \%$ & $67,74 \%$ & $0 \%$ & $19,03 \%$ & $0 \%$ & $0 \%$ \\
\hline
\end{tabular}


pencapaian mengalami peningkatan untuk kategori sangat baik yaitu dari $32,26 \%$ menjadi $48,39 \%$. Akan tetapi untuk kategori baik mengalami penurunan, dari $67,74 \%$ menjadi $51,61 \%$, dan kategori kurang baik dan buruk $0 \%$. Pada kelas kontrol pertemuan 1 diperoleh hasil untuk kategori sangat baik pencapaiannya $6,40 \%$, baik $77,74 \%$, kurang baik $15,90 \%$, dan buruk $0 \%$. Pertemuan ke-2 pencapaian kategori sangat baik $0 \%$, baik $64,52 \%$, kurang baik $35,48 \%$, dan buruk $0 \%$. Kategori sangat baik pada pertemuan ke-3 pencapaiannya sebesar $13,23 \%$, baik $67,74 \%$, kurang baik $19,03 \%$, buruk $0 \%$. Hasil penilaian afektif pada kelas eksperimen dan kelas kontrol tersebut terangkum pada tabel 2

Berdasarkan data hasil penilaian psikomotor siswa, terdapat 5 indikator yang dinilai dan penilaiannya dianalisis menggunakan skala likert ${ }^{[4]}$. Pada pertemuan 1 di kelas eksperimen, setelah dijumlahkan hasil persentase dari semua pencapaian indikator, diperoleh hasil sebesar $82,97 \%$ dengan kategori sangat baik. Pertemuan ke-2 dengan hasil 82,97\% dengan kategori sangat baik, dan kategori yang sama pada pertemuan ke-3 dengan hasil 88,52\%. Analisis yang sama dilakukan juga pada kelas kontrol dengan perolehan hasil perhitungan sebesar $76,61 \%$ pada pertemuan 1 dan termasuk kategori baik. Pencapaian meningkat pada pertemuan ke-2 dan ke-3 dengan kategori sangat baik dengan persentase sebesar $82,58 \%$ pertemuan ke-2, dan $85,03 \%$ pada pertemuan ke-3. Hasil penilaian psikomotor pada kelas eksperimen dan kelas kontrol terdapat pada gambar 1.
Hasil penilaian afektif dan psikomotor kelas eksperimen dan kelas kontrol, diperoleh hasil belajar yang lebih baik pada kelas eksperimen. Hal tersebut disebabkan karena, metode pembelajaran pemecahan masalah (problem solving) merupakan salah satu metode pembelajaran yang mampu memicu motivasi siswa dalam kegiatan belajar. Metode pemecahan masalah juga berperan dalam mengembangkan aktivitas siswa, yang terbukti dari hasil kuesioner terhadap aktivitas siswa menunjukkan bahwa sebagaian besar siswa telah melaksanakan dengan baik tahap-tahap pembelajaran [8].

Materi yang dipilih pada penelitian ini adalah materi ekosistem. Materi tersebut sesuai dengan beberapa kriteria pemilihan bahan pelajaran dalam penggunaan metode pemecahan masalah, merupakan materi yang bersifat familiar dengan siswa, permasalahan yang muncul bisa bersumber dari berita, rekaman video dan lainnya. Selain itu pada materi ekosistem terdapat permasalahan yang bersumber dari peristiwa-peristiwa dalam kehidupan sehari-hari siswa yang sesuai dengan kurikulum dan mendukung tercapainya tujuan pembelajaran yang telah ditetapkan. Adanya permasalahan yang behubungan dengan kehidupan sehari-hari siswa membuat siswa merasa lebih bersemangat dalam belajar serta lebih memahami materi pembelajaran karena mendapatkan pengalaman belajar sendiri.

Hasil observasi aktivitas guru dengan menggunakan pedoman IPKG menunjukkan bahwa pada pertemuan 1 di kelas eksperimen, sebagian besar indikator terlaksana dengan baik dan pada pertemuan ke-2 dan ke-3 sebagian besar indikator terlaksana dengan baik sekali, begitu juga dengan kelas kontrol, sehingga

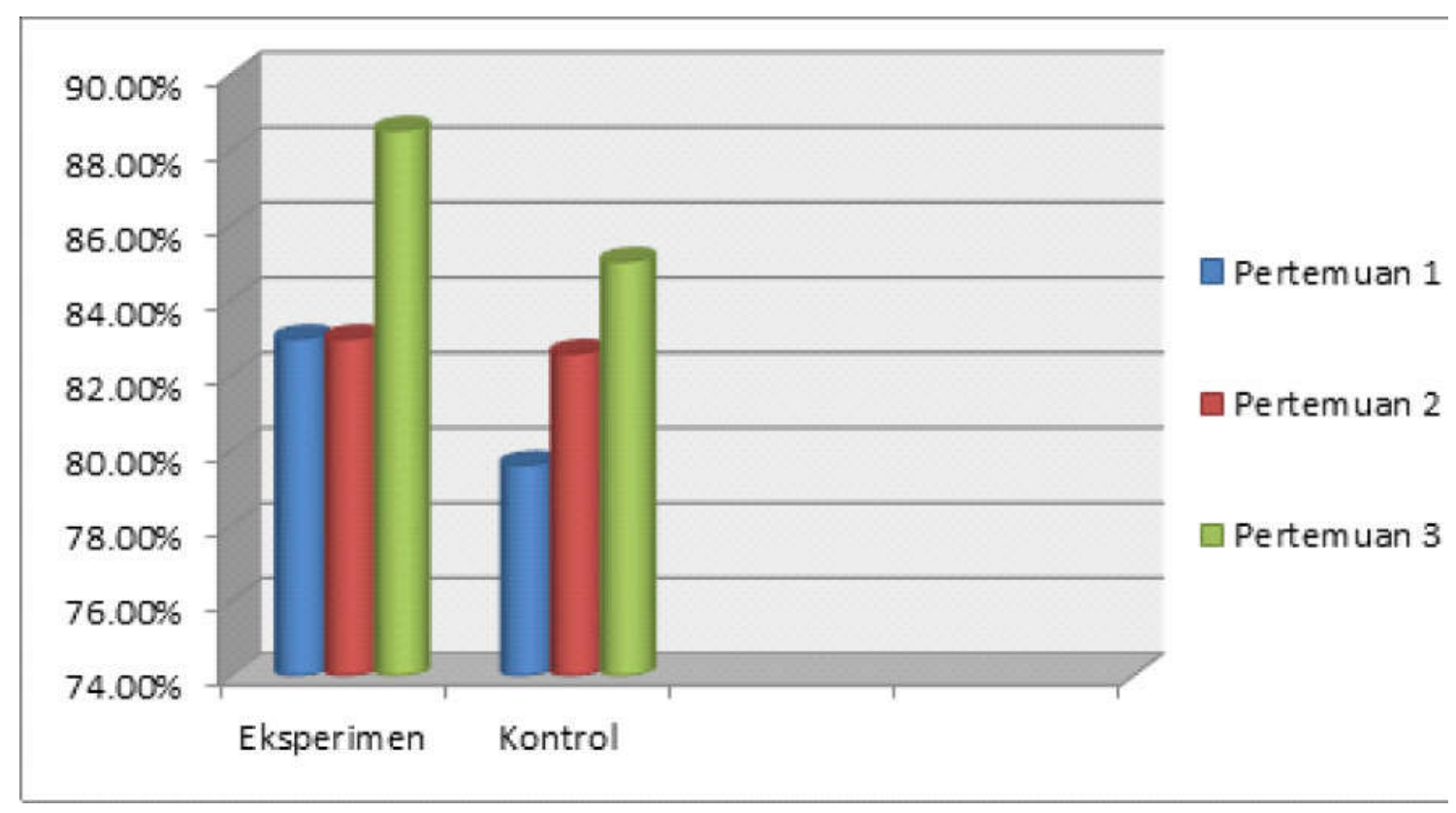


diperoleh hasil pada setiap pertemuan sebagian besar indikator terlaksana dengan baik.

Hasil observasi aktivitas siswa pada kelas eksperimen dengan pembelajaran menggunakan metode pemecahan masalah (problem solving) seluruhnya telah terlaksana dan diperoleh hasil pada pertemuan 1 dengan rata-rata skor 70 dengan kategori sangat aktif, pada pertemuan ke-2 dengan rata-rata skor 75 , dan pada pertemuan ke-3 dengan rata-rata skor 77 dengan kategori sangat aktif.Hal ini menunjukkan bahwa kegiatan siswa pada kelas eksperimen dengan metode pemecahan masalah (problem solving) telah terlaksana dengan rata-rata aktivitas siswa sangat aktif. Pada penilaian lembar observasi aktivitas siswa kelas kontrol diperoleh jumlah rata-rata skor 37 untuk pertemuan 1, dengan kategori aktif. Pertemuan 2 dengan ratarata skor 40 dengan katagori sangat aktif. Pertemuan 3 dengan rata-rata skor 37 , dan masuk kategori aktif.

Proses pembelajaran pemecahan masalah bukan tanpa kendala dalam pelaksanaannya. Kendala yang nyata adalah bahwa siswa membutuhkan waktu lebih banyak untuk melakukan diskusi dengan anggota kelompoknya. Untuk mengatasi hal tersebut maka dilakukan pembatasan waktu presentasi, membatasi jumlah pertanyaan yang diajukan oleh masing-masing kelompok, ataupun masukan yang diberikan oleh kelompok lain.

\section{KESIMPULAN}

Berdasarkan hasil penelitian yang diperoleh, dapat disimpulkan bahwa penerapan metode pembelajaran problem solving efektif dalam meningkatkan hasil belajar (kognitif) biologi siswa kelas X SMA Negeri 3 Mataram tahun pembelajaran 2010/ 2011 pada pokok bahasan "Ekosistem".

\section{DAFTAR PUSTAKA}

[1] Sanjaya, W. 2009. Strategi Pembelajaran Berorientasi Standar Proses Pendidikan. Jakarta: Kencana.

[2] Nurkencana, W. 1990. Evaluasi Pendidikan. Surabaya: Usaha Nasional.

[3] Sudjana, D. 2005. Metode dan Teknik Pemebalajaran Partisipatif. Bandung: Falah Production.

[4] Arikunto, S. 2006. Prosedur Penelitian Suatu Pendekatan Praktik. Jakarta: Rineka Cipta.

[5] Sugiyono. 2008. Statistika Untuk Penelitian. Bandung : CV Alfabeta.

[6] Tim Sertifikasi Dikti. 2006. IPKG Biologi. Jakarta: Depdiknas Direktorat Jendral Pendidikan
Dasar dan Menengah Direktoran Pendidikan Lanjutan Pertama.

[7] Sudjana, D. 2000. Strategi Pembelajaran. Bandung: Falah Production.

[8] Fitriyanti. 2009. Jurnal Pengaruh Penggunaan Metode Pemecahan Masalah Terhadap Kemampuan Berpikir Rasional Siswa. http://fitriyanti.blogspot.com/2009/05/ pengaruh-penggunaan-metode-pemecahan-masalah-terhadapkemampuan-berpikir-rasional-siswa-pembelajaran-ekonomikelas-xi-sma-srijaya-negara-palembang-html/. Diakses tanggal 26 Mei 2011.

[9] Susilowati, H. 2007. Pengaruh Keterampilan Berproses Model SPembelajaran Problem Solving Terhadap Hasil Belajar Pokok Bahasan Segitiga Pada Siswa SMPN 15 semarang. Skripsi Program S1 Jurusan Pendidikan Ilmu Pengetahuan Alam. Semarang: UNNES. http:// digilib.unnes.ac.id/gsdl/collect/skripsi/archives/ HASHeo05.dir/doc.pdf. Diakses tanggal 20 September 2010.

[10] Depdiknas. 2002. Materi Pelatihan Terintegrasi Ilmu Pengetahuan Alam. Jakarta: Depdiknas Direktorat Jenderal Pendidikan Dasar Dan Menengah Direktorat Pendidikan Lanjutan Pertama. 